\title{
Technology Review and Selection Guide for Industry Wastewater Treatment
}

\author{
Yuanfan Li \\ Department of Water Conservancy and Hydropower Engineering, Hohai University, Nanjing, China \\ Email: helenliyuanfan@gmail.com
}

How to cite this paper: Li, Y.F. (2020) Technology Review and Selection Guide for Industry Wastewater Treatment. Computational Water, Energy, and Environmental Engineering, 9, 22-35.

https://doi.org/10.4236/cweee.2020.92003

Received: March 11, 2020

Accepted: April 23, 2020

Published: April 26, 2020

Copyright (C) 2020 by author(s) and Scientific Research Publishing Inc. This work is licensed under the Creative Commons Attribution International License (CC BY 4.0).

http://creativecommons.org/licenses/by/4.0/

(c) (i) Open Access

\begin{abstract}
Water pollution has become one of the most pressing health crises in the world. Water pollution control began as early as the late 1800s. In 2008, there were 14,780 municipal wastewater treatment plants operating in the United States. These plants range in size from a few hundred gallons per day (GPD) to over 1.445 billion gallons (MGD) per day. Wastewater treatment facilities are designed and constructed or upgraded to reduce the amount and diversity of pollutants. This article gives a review of the current industrial wastewater treatment technology in recent years, including treatment principles, advantages and disadvantages of each method, and the corresponding applications. Also, this article reviewed two common biological technologies Anaerobic Ammonium Oxidation (ANAMMOX) and Anaerobic Membrane Bioreactor (ANMBR) technology, by assessing their advantages, disadvantages, and costs, and provides resources for further technical research. This article can serve as a guide for anyone seeking information on innovative and emerging industry wastewater treatment technologies.
\end{abstract}

\section{Keywords}

Industrial Wastewater Treatment, ANAMMOX, ANMBR

\section{Introduction}

It is true that the rapid growth of industrial development has led to the generation of large amounts of wastewater containing many organic compounds that are unacceptable to the environment and human health. According to a research report by Global Environment Protection Research (GEP Research) in 2018 [1], there was an increasing trend in both total wastewater discharge and residential wastewater discharge while industrial wastewater dropped from 2015 (roughly 19,500 million tons) to 2018 (about 17,500 million tons), as Figure 1 shows. 


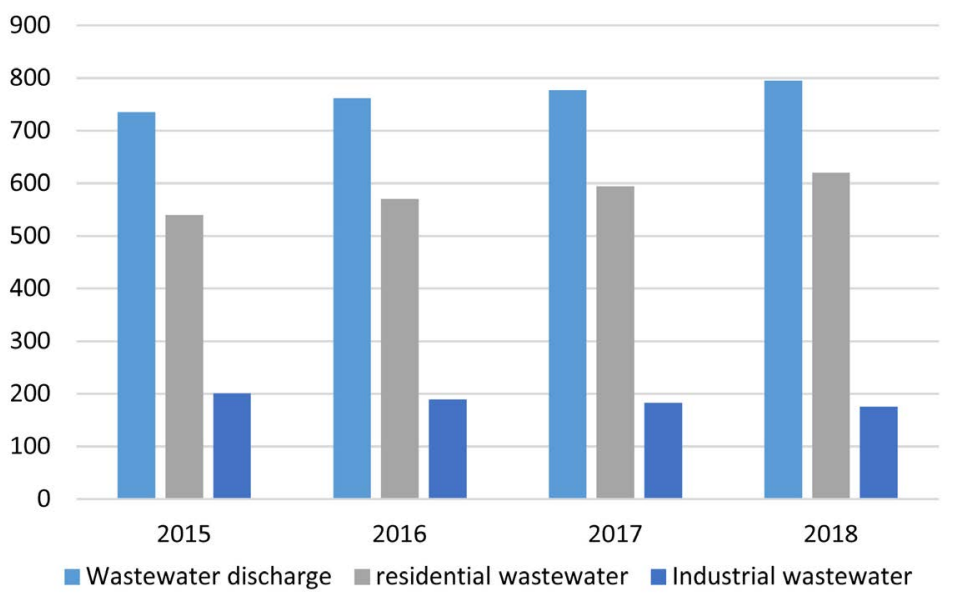

Figure 1. China's wastewater discharge by sector (unit: 100 million tons).

Although the proportion of industrial wastewater has decreased slightly, its total amount is still very large. At the same time, the water quality of Chinese lakes is not optimistic. In 2016, according to the People's Republic of China's Surface Water Environmental Quality Standards, China's water quality is classified into five categories: I, II, III, IV, V, and inferior V, based on the environmental functions and protection objectives of surface water.

The Ministry of Water Resources conducted water quality assessments on a total of 31,000 square kilometers of water in 118 lakes. In the whole year, there were 28 lakes with I - III water quality, 69 lakes with IV to V, and 21 lakes with poor $\mathrm{V}$, accounting for $23.7 \%, 58.5 \%$ and $17.8 \%$ of the total lakes, respectively [2].

If wastewater is not handled properly, it will have a negative impact on the environment and human health. These effects may include hazards to fish and wildlife populations, oxygen consumption, beach closures and other restrictions on recreational water use, restrictions on harvesting of fish and shellfish, and contamination of drinking water.

This paper reviews the advantages and disadvantages of the existing wastewater treatment methods for industrial wastewater treatment from three different methods, physical, chemical, and biological. It also provides detailed review of two popular biological treatment processes in recent years, Anaerobic Ammonium Oxidation (ANNAMOX), which is a relatively mature technology and Anaerobic Membrane Bioreactor (ANMBR), which is a promising technology but still under study. These two are common biotechnology anaerobic oxidation technologies, which meet people's increasing requirements for industrial wastewater treatment. This article explains these two methods, in particular, and makes a simple comparative analysis of these two from several aspects such as efficiency.

\section{Chemical Methods of Wastewater Treatment}

The chemical treatment of wastewater can produce condensation of colloidal 
suspensions generate insoluble solids and gases, produce biodegradable substances from non-biodegradable, destroy or inactivate chelating agents and produce substances that can be easily removed in order to remove substances in wastewater. The coagulant binds the colloidal particles together by slow agitation. Certain highly objectionable materials can be chemically oxidized to produce non-objectionable materials such as $\mathrm{CO}_{2}$ and water. For bio-refractive compounds in industrial wastewater that have not been completely removed by biological treatment, other physical and/or chemical treatments must be performed to enhance their biodegradability.

\subsection{Method Summary}

Advanced Oxidation Processes (AOPs) are a set of common chemical wastewater treatment procedures. AOPs are designed to remove organic and some inorganic materials from water and wastewater by oxidation with hydroxyl radicals $(\bullet \mathrm{OH})$. However, in the real world, wastewater treatment applications generally refer to more specifically to a portion of the chemical process using ozone $\left(\mathrm{O}_{3}\right)$, hydrogen peroxide $\left(\mathrm{H}_{2} \mathrm{O}_{2}\right)$ and/or ultraviolet light. One such method is known as in situ chemical oxidation [3] as below Figure 2 shows.

AOP has below unparalleled advantages in wastewater treatment field:

1) It can effectively eliminate organic compounds in the aqueous phase, rather than collecting or transferring contaminants to another phase.

2) Due to the significant reactivity of $\bullet \mathrm{OH}$, it can react with almost all aqueous contaminants without distinction. Therefore, AOP is suitable for many, if not all, scenarios where many organic contaminants must be removed at the same time.

3) Some heavy metals can also be removed in the form of precipitated $\mathrm{M}(\mathrm{OH})_{\mathrm{x}}$.

4) Disinfection can also be achieved in some AOP designs, making these AOPs an integrated solution to certain water quality problems.

5) Since the complete reduction product of $\bullet \mathrm{OH}$ is $\mathrm{H}_{2} \mathrm{O}$, AOP does not theoretically introduce any new harmful substances into the water.

However, it should be recognized that AOP also has several drawbacks.

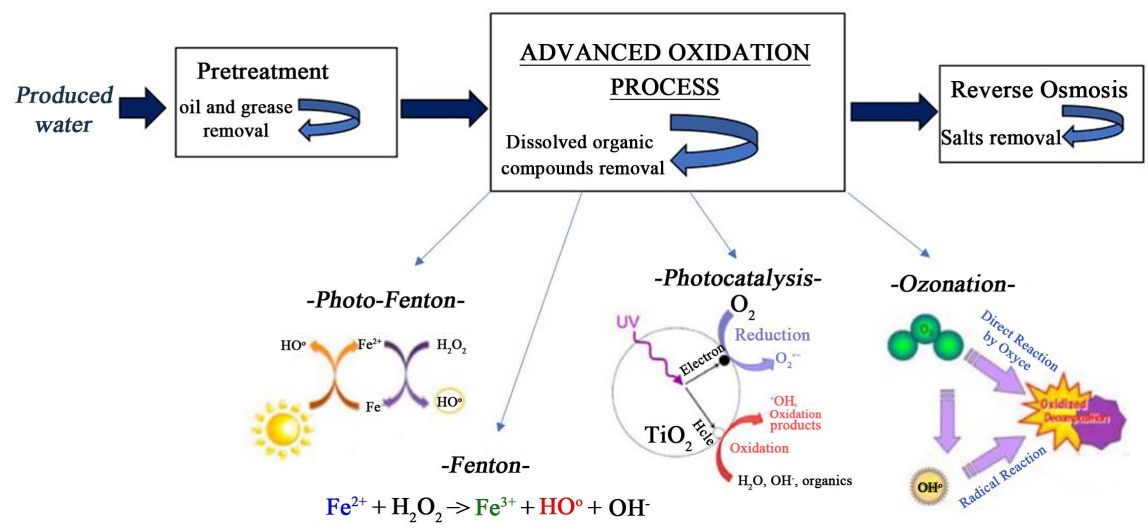

Figure 2. Flowchart of in situ chemical oxidation process. 
1) Most notably, the cost of AOP is quite high because of the need to continuously import expensive chemicals to maintain the operation of most AOP systems. Due to its nature, AOP requires hydroxyl radicals and other reagents that are proportional to the amount of contaminants to be removed.

2) Some technologies require pre-treatment of wastewater to ensure reliable performance, which can result in potential cost and technical requirements. For example, the presence of bicarbonate ions $\left(\mathrm{HCO}_{3}^{-}\right)$can significantly reduce the concentration of $\bullet \mathrm{OH}$, since the scavenging process produces $\mathrm{H}_{2} \mathrm{O}$ and less reactive species $\mathrm{CO}_{3}^{-}$. As a result, bicarbonate must be removed from the system, which would otherwise damage the AOP.

Therefore, it is not cost effective to use only AOP to process large amounts of wastewater. Instead, AOP should be deployed in the final stages after the primary and secondary treatments have successfully removed most of the contaminants.

\subsection{Industry Application Illustration Results}

In fact, there have been some industry applications that have provided constructive solutions. For example, doping $\mathrm{TiO}_{2}$ with a non-metallic element can enhance photocatalytic-activity. Sonication may promote the production of hydroxyl radicals [4].

Now, this technology has been used in some industries, such as the pulp and paper industry. Due to the extremely low biodegradability of some pulp and paper mill wastewater (the BOD/COD ratio is very low), a study of the combination of pre-oxidation or post-oxidation and biodegradation of ultrasonic treated AOPs has shown that the toxicity of paper mill wastewater Eventually reduced and increased biodegradability [5]. The bleached non-biodegradable wastewater from cellulose and paper was first treated with coagulation and flocculation, and then treated with a $\mathrm{UV} / \mathrm{TiO}_{2} / \mathrm{H}_{2} \mathrm{O}_{2}$ system using a mercury lamp to increase the biodegradation index from 0.11 to 0.71 [6] [7].

\section{Physical Methods of Wastewater Treatment}

\subsection{Method Summary}

A solution that applies physical effects without changing the composition of the wastewater is called a physical method of wastewater treatment. After the physical treatment, the wastewater does not change the chemical nature of the pollutants, but only separates the pollutants from water. The physical method of wastewater treatment is the use of forces that occur naturally (such as gravity, electro-gravity, and van der Waals forces) and physical barriers to remove substances. The physical methods of Wastewater Treatment (WWT) involve sedimentation, flotation, and adsorption, as well as barriers such as screens, membranes, electro-dialysis, and ion exchange.

Total Suspended Solids (TSS) is a solid substance that is trapped on the membrane through a filter with a pore size of $0.45 \mu \mathrm{m}$ and dried to a constant weight 
at $103^{\circ} \mathrm{C}-105^{\circ} \mathrm{C}$ [8]. It is one of the important indicators for measuring the degree of water pollution in water. In most wastewater treatment, the separation of TSS from waste from any industry is an important part, which can eliminate most of the pollutants and separate one type of pollutant for easier and more economical further processing. The flotation of small particles in suspension can be flocculated and floated on the surface of the liquid and removed by skimming. And we can separate TSS from industrial wastewater through membrane reaction. Membrane processes can enhance conventional processes by concentrating the components in a reactor (e.g. Membrane Bioreactor (MBR)). Membrane technology has good water recycling efficiency, which can meet the water recyclable needs of many food industries and other industries [9].

\subsection{Industry Application Illustration}

In the food and beverage industry, physical treatment method is commonly used in the treatment of sewage. The food and beverage industry is a major consumer of water, consuming up to $10-12$ tons of water per ton of product or even more [10] [11]. Severely contaminated oil IWW contains a small amount of light oil. The IWW is processed by gravity oil separator, dissolved air flotation and traditional biological devices, reducing the high content of fats and oils (B \& D), Biochemical Oxygen Demand (BOD), Chemical Oxygen Demand (COD) and TSS to the limit that allows sewage to be discharged into public sewage [12]. MBRs of microfiltration hollow fiber were used to treat industrial oil-contaminated wastewater with high removal efficiency (about 98\%), thereby obtaining reusable highly purified water [13].

\section{Biological Methods of Wastewater Treatment}

Biological methods of wastewater treatment can be applied to carbonaceous organics, representing the removal of BOD, nitrification, denitrification, stabilization and phosphorus removal. In general, biological processes can be classified as aerobic or anaerobic (hypoxia and anaerobic). Aerobic biological processes usually achieve higher treatment efficiency, while anaerobic bacteria use the concept of resource recovery and utilization to control pollution.

In recent years, high anaerobic/aerobic bioreactors have been increasingly used to degrade high-intensity IWW. High anaerobic/aerobic bioreactors have the smallest space requirements with traditional methods, lower investment costs and good COD removal efficiency (over 83\%) [14]. For example, it is reported that the anaerobic upflow blanket filter "UBF" membrane bioreactor (MBR) system is used in the treatment of high-intensity wastewater with a relatively strong COD range of $6000-14,500 \mathrm{mg} / \mathrm{L}$, as Figure 3 shows [15]. The COD removal rate was $99 \%$.

Similarly, the staged anaerobic/aerobic MBR of the membrane module immersed in the aerobic zone has been successfully used to treat high-strength synthetic wastewater containing COD up to $10,500 \mathrm{mg} / \mathrm{L}$ and $\mathrm{NH}_{4}^{+}-\mathrm{N}$ up to 1220 $\mathrm{mg} / \mathrm{L}$ [16], as Figure 4 shows [16]. 


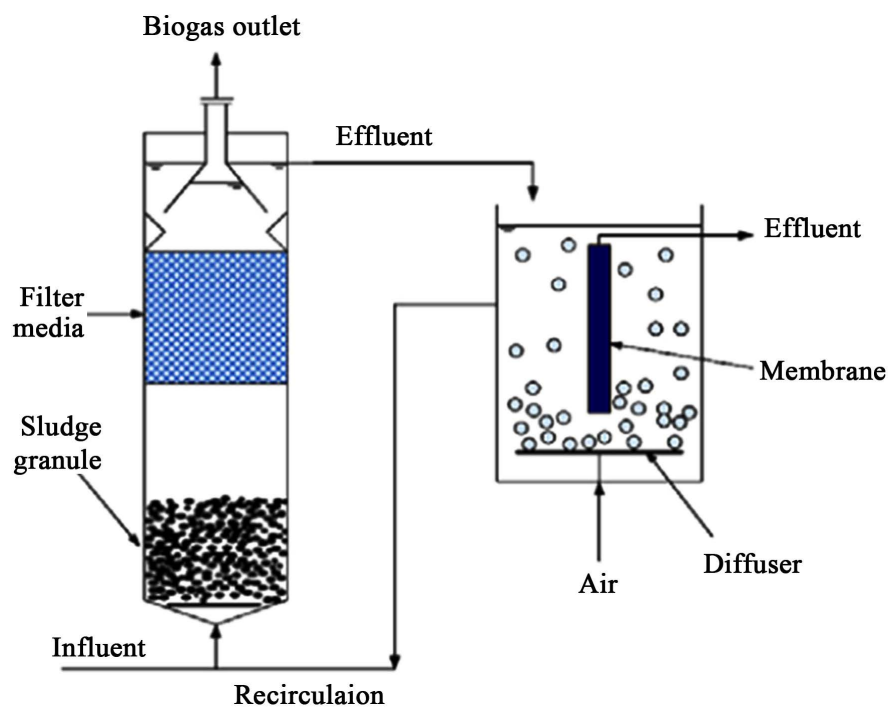

Figure 3. Schematic diagram of UBF-aerobic MBR system (2007) [16].

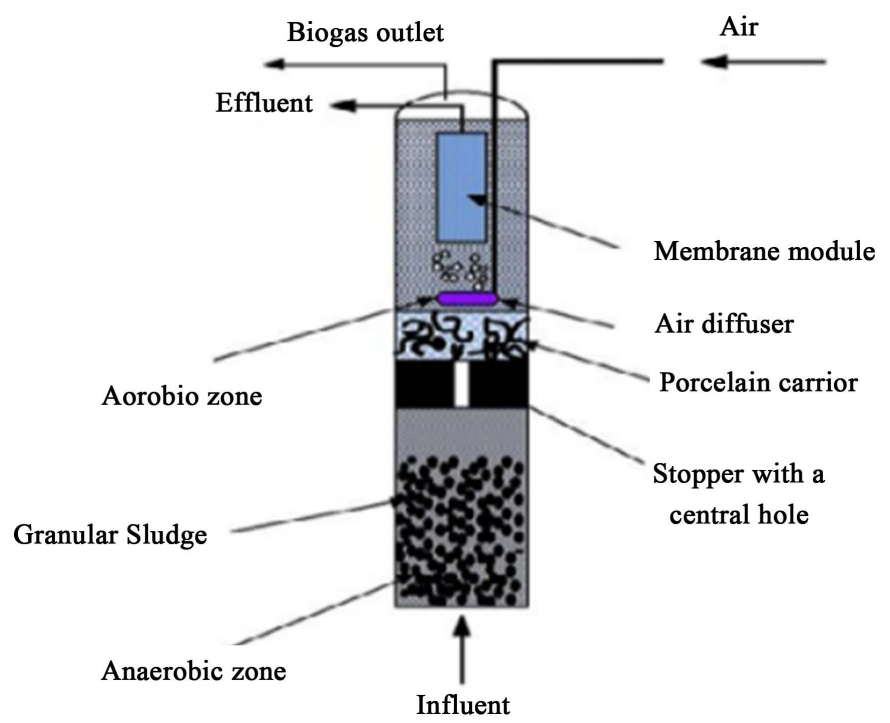

Figure 4. Schematic diagram of staged anaerobic-aerobic MBR [16].

\subsection{ANAMMOX}

Anaerobic Ammonium Oxidation (ANAMMOX) has been a relatively competitive and mature industrial biological wastewater treatment technology recently. It is an advanced biological denitrification alternative to traditional nitrification-denitrification. Anaerobic ammoxidation uses nitrite $\left(\mathrm{NO}^{2-}\right)$ as an electron acceptor to convert ammonia $\left(\mathrm{NH}_{4}^{+}\right)$into nitrogen $\left(\mathrm{N}_{2}\right)$ under anoxic conditions [17]. At the same time, the biological process of fixing $\mathrm{CO}_{2}$ with nitrite as electron donor and producing nitrate $\left(\mathrm{NO}_{3}^{-}\right)$was accompanied [18]. The microorganisms that perform this process are called Anaerobic Ammonium Oxidation Bacteria (AAOB). Below shows the chemometric equations [19]:

Reaction 1: $\mathrm{NH}_{4}^{+}+\mathrm{NO}_{2}^{-}=\mathrm{N}_{2}+2 \mathrm{H}_{2} \mathrm{O}$

Reaction 2: $\mathrm{NO}_{2}^{-}+2 \mathrm{H}^{+}+\mathrm{e}=\mathrm{NO}+\mathrm{H}_{2} \mathrm{O}$ 


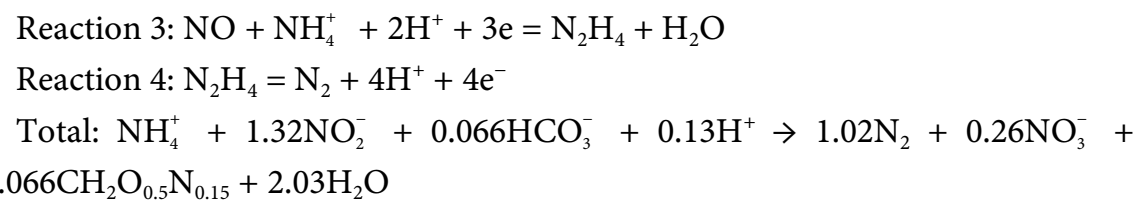

Reaction $1 \& 2$ are the first step to reduce nitrite from nitric oxide by nitrate reductase. Reaction 3 is the second step where ammonium is combined with nitric oxide by hydrazine hydrolase to the form of hydrazine. Reaction 4 is the final step where hydrazine is oxidized to dinitrogen gas via hydrazine/hydroxylamine oxidoreductase [20]. Reaction 5 combines all the reaction equations together.

\subsubsection{Advantages of ANAMMOX}

Compared with the traditional nitrification-denitrification process, ANAMMOX has the following four advantages (Figure 5) [21]: 1) ANAMMOX is performed under hypoxic conditions, which can save energy, as shown in Figure 4, $1 \mathrm{~mol}$ $\mathrm{NH}_{4}^{+}$reduces the use of 1.1 mol oxygen; 2) ANAMMOX uses inorganic carbon $\left(\mathrm{CO}_{2}\right.$ or $\left.\mathrm{HCO}_{3}^{-}\right)$as the carbon source, without the need to add organic carbon, which greatly saves the carbon source; 3) The ratio of $\mathrm{CO}_{2}$ produced by ANAMMOX to ordinary nitrification-denitrification system is reduced; 4) The increase of anaerobic ammonium oxide removal rate and nitrogen removal amount can reduce process protrusions and reduce process infrastructure costs.

\subsubsection{Disadvantages of ANAMMOX}

The ANAMMOX process has broad application prospects in the field of biological nitrogen removal due to its advantages of high efficiency and low consumption. However, there are still some defects in engineering applications, such as process disturbances, nitrogen accumulation, greenhouse gas emissions, which will affect the effect of process operation.

Take process disturbance as an example. Currently, there are approximately 100 ANAMMOX projects in operation or under construction and planning.

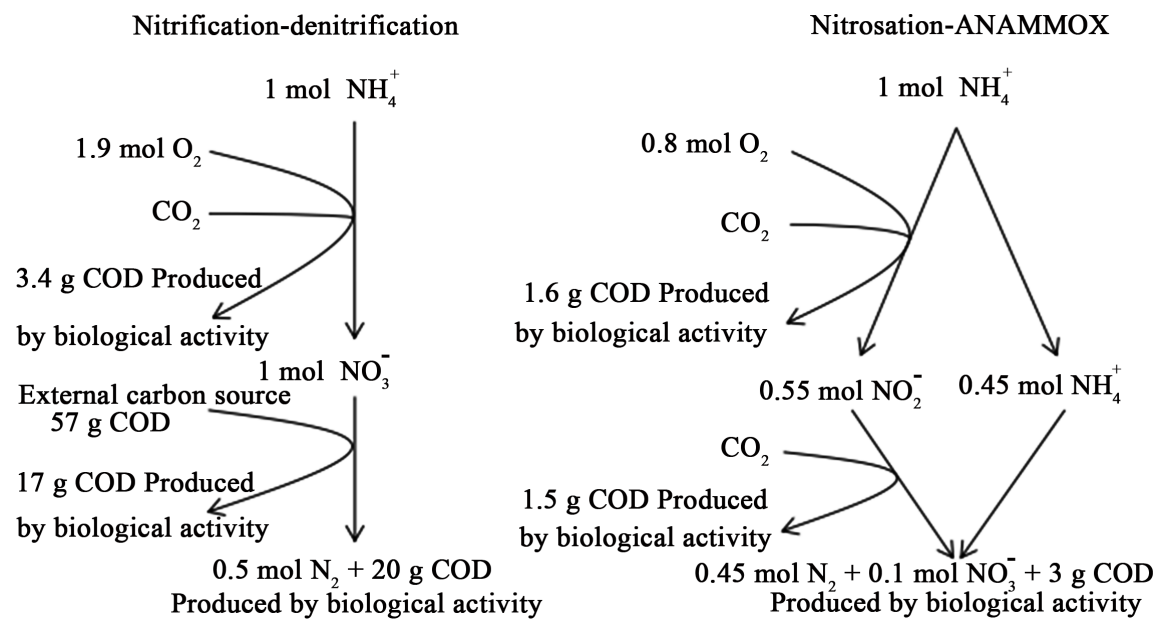

Figure 5. Comparison between nitrification-denitrification (left) and the nitritation-anammox process (right) (2008) [21]. 
PN-ANAMMOX (Partial nitrification, PN) is one of the relatively mature processes. In fact, only a few sewage plants affect the process performance due to hardware problems (blower, mixing equipment, pumps). Some operating parameters usually affect the process performance. For example, the most commonly used control parameter, DO concentration (Dissolved Oxygen concentrations). When the DO sensor fails, it will lead to serious consequences, that is, if too high exposure gas intensity is not controlled in time, it will lead to nitrate accumulation. An increase in nitrate concentration means an imbalance in the function of different microbial physiological groups. Eventually have an adverse effect on the process operation effect.

\subsection{ANMBR}

Anaerobic Membrane Bioreactor (ANMBR) technology is a combination of anaerobic biological treatment and physical membrane separation. ANMBR system is available in several different configurations. The main elements of the ANMBR system are a primary anaerobic bioreactor and a secondary membrane bioreactor. The wastewater in the main anaerobic bioreactor converts organic carbon and related five-day biochemical aerobic microorganisms (BOD 5) into energy-rich methane and carbon dioxide-containing biogas. The biogas produced in the primary anaerobic bioreactor can be used for power generation, heating or as vehicle fuel. The secondary membrane bioreactor contains an ultrafiltration (UF) membrane that separates microorganisms and other suspended solids from the treated wastewater (permeate). In ANMBR, the seed culture of the anaerobic digester of the sewage treatment plant is used for batch recycling, and then a semi-continuous process and continuous operation are performed to establish anaerobic ammonia oxidation activity in the anaerobic digester. Over the course of a year, with changes in Nitrogen Loading Rate (NLR) and Hydraulic Retention Time (HRT), the performance of ANMBR has been shown to translate from nitrogen to ammonia, nitrite and nitrate, as well as hydroxybenzoic acid and hydroxylamine.

\subsubsection{Advantages of ANMBR}

For ANMBR, membrane module to replace secondary sedimentation tank in traditional activated sludge process, which can maintain high activated sludge concentration in the bioreactor and increase the organic load of biological treatment, thereby reducing the footprint of sewage treatment facilities and reducing the amount of remaining sludge by keeping the sludge load low. ANMBR has the following main advantages:

1) Due to the membrane, ANMBR is capable to fade concentration and hydraulic peaks unlike conventional anaerobic technologies and thus tolerate fluctuations in organic loading [22]. The membrane ensures that biomass is separated from the effluent; hence this technology shows great promise for the treatment of wastewaters that negatively impact granular biomass in high-rate anaerobic reactors [23] [24]. 
2) Unlike other anaerobic treatment techniques, the effluent quality of ANMBR is often unaffected by biomass sedimentation or changes in pelleting performance. Finally, because the membrane completely retains biomass, fast system operation recovery is achieved. According to Tao et al. [25] and Fanlier [26], membranes represent a total barrier to slowly growing microorganisms that can be removed from specific pollutants that accumulate in industrial wastewater, regardless of hydraulic retention time (HRT). For example, Tao et al. increased the activity of slow-growing ANAMMOX microorganisms by 19 times through membrane preservation [25].

3) The membrane bioreactor with a small footprint can maintain a high sludge concentration. Generally, the MLSS is $8-20 \mathrm{~g} / \mathrm{L}$, which is 2.5 - 5 times that of traditional biological treatment [27]. At the same time, the system eliminates the secondary sedimentation tank and sludge return equipment, which could save some costs and land.

4) In addition to membrane-related advantages, ANMBR offers other significant operational advantages. For example, since the biotransformation of organics does not require oxygen, the overall energy consumption is reduced. Since oxygen is not required, the operating costs of the ANMBR plant are greatly reduced, and a significant portion of the electricity and heating required to operate the plant can be provided by the biogas produced. The extent to which these costs are paid will depend on biomass production [28]. For example, the total cost of ANMBR for treating Kraft plant wastewater is significantly lower than that of aerobic treatment [29].

\subsubsection{Disadvantages of ANMBR}

Although ANMBR shows many advantages over "conventional" systems and below are two examples: 1) The most serious disadvantage of ANMBR is membrane fouling [23] [30]. Fouling that leads to reduced hydraulic performance limits the widespread application of membrane technology [31] [32]. Membrane fouling is mainly caused by the deposition and accumulation of microorganisms, colloids, solutes, and cell debris on or in the membrane [30] [31]. An important part of the irreversible scaling of the ANMBR membrane [33] is mainly struvite $\left(\mathrm{MgNH}_{4} \mathrm{PO}_{4}\right.$; magnesium ammonium phosphate), which is also an important part of the irreversible scaling of the ANMBR membrane [33]. The performance and operating parameters of the membrane can play an important role in the precipitation rate of inorganic compounds. E. Meabe showed that struvite fouling increased at higher operating temperatures $\left(55^{\circ} \mathrm{C}\right.$ and $\left.35^{\circ} \mathrm{C}\right)$ due to an increase in ammonia nitrogen concentration [34];2) Compared to aerobic MBR, filter cakes that are usually formed on ANMBR membranes are more difficult to remove, which means that more concentrated chemicals, higher temperatures and/or longer exposure times are required to perform more stringent cleaning procedures.

\subsection{Comparing ANAMMOX and ANMBR}

ANAMMOX and ANMBR are both anaerobic wastewater treatment technologies, but their principles and production applications are different. 
ANAMMOX uses nitrite $\left(\mathrm{NO}_{2}^{-}\right)$as the electron acceptor, and converts ammonia $\left(\mathrm{NH}_{4}\right)$ into nitrogen $\left(\mathrm{N}_{2}\right)$ under the action of anaerobic ammonium oxidizing bacteria (AAOB) under the condition of hypoxia. This is a biological process in which an electron donor fixes $\mathrm{CO}_{2}$ and produces nitrate $\left(\mathrm{NO}_{3}^{-}\right)$. At present, the ANAMMOX process has been successfully applied to the treatment of high-concentration nitrogen-containing wastewater such as sludge digestion liquid, landfill leachate, monosodium glutamate wastewater, and pig farm wastewater, and has reached a production scale.

In contrast, anaerobic membrane bioreactor (ANMBR) is a new water treatment technology that combines membrane separation technology with anaerobic biological treatment equipment. The ANMBR process is divided into two stages: anaerobic digestion and membrane separation. Among them, there is no difference between the anaerobic digestion stage and the anaerobic treatment process. The main difference between the membrane separation stage and the aerobic MBR is that the membrane surface is not swept by aeration. To date, the ANMBR pilot plant has been used to highly treat different levels of organic matter in wastewater, such as organics from food processing and industrial uses, pulp and paper industry, textile production and polymer synthesis. Recently, laboratory and pilot scale ANMBR plants have been used to treat different food processing wastewater, such as molasses production and landfill leachate. Table 1 compares the removal efficiency and time consuming of ANAMMOX and ANMBR from organic matter [35] [36] [37].

\section{Observations \& Recommendations}

In recent years, more and more factories are under construction. The sewage from factories also has many adverse effects on the natural environment and human beings. Although the discharge of industrial wastewater is decreasing

Table 1. Comparison of ANAMMOX and ANMBR.

\begin{tabular}{|c|c|c|c|}
\hline & $\begin{array}{c}\text { Traditional } \\
\text { anaerobic technology }\end{array}$ & ANAMMOX & ANMBR \\
\hline $\begin{array}{l}\text { Organic matter } \\
\text { removal efficiency }\end{array}$ & high & high & high \\
\hline Duration & $\begin{array}{c}\text { Slow } \\
\text { (about } 2-4 \text { months) }\end{array}$ & $\begin{array}{l}\text { Slow growth (doubling } \\
\text { time is about } 11 \mathrm{~d} \text { ) }\end{array}$ & $\begin{array}{l}\text { Less than } \\
\text { two weeks }\end{array}$ \\
\hline Temperature sensitivity & Relatively low & medium & Relatively low \\
\hline Organic load factor & High & High & high \\
\hline Sludge production & low & lower & lowest \\
\hline $\begin{array}{l}\text { BOD and COD } \\
\text { removal efficiency }\end{array}$ & Relatively low & $\begin{array}{c}\text { High } \\
(74 \% \pm 15 \%)\end{array}$ & $\begin{array}{c}\text { Highest (>90\%) } \\
{[35]}\end{array}$ \\
\hline HRT & - & 2 hours & $6-8$ hours \\
\hline Operating costs & low & high & high \\
\hline
\end{tabular}


year by year, the quality of industrial wastewater still needs to be improved. According to this demand, this article reviews the recent industrial wastewater treatment technologies, including their treatment principles, advantages and disadvantages, and corresponding applications.

In addition, this paper compares two relatively effective and competitive biotechnology anaerobic oxidation technologies (ANAMMOX) and anaerobic membrane bioreactor (ANMBR) from the aspects such as organic removal rate and time consumption, which provides resources for further technical research. I have some comments and suggestions on this. Although ANMBR has gained popularity, it has some obvious drawbacks. Below are two observations and corresponding recommendations:

1) Membrane fouling will affect the effectiveness of ANMBR in practical applications. The specific manifestation of membrane fouling is attenuation of membrane flux or increase in transmembrane pressure difference (TMP). Although ANMBR has obvious advantages in applications such as low-concentration industrial wastewater and high-concentration applications, membrane pollution has hindered the promotion and application of ANMBR, which is a recognized fact in the industry [38].

2) It is still a challenge about how to determine the proper methods and frequency for cleaning membranes. On the one hand, RAMOS etc. [19] proved that the immersion type chemical cleaning method made the overall purification efficiency as high as $91 \%$ or higher. On the other hand, if chemical cleaning is used, chemical cleaning will consume chemicals and cause secondary pollution to water. Therefore, the next problem we need to solve is how to control the cleaning frequency and whether it can reduce the secondary pollution of these chemicals to water.

For future reference, the above observations can be taken into consideration when deciding what kind of industrial waste treatment technology should be used, and this paper can serve as a good guide.

\section{Conflicts of Interest}

The author declares no conflicts of interest regarding the publication of this paper.

\section{References}

[1] (2018) China's Environmental Protection Industry Market Status and Development Trends in 2018. https://www.sohu.com/a/288182765_100067384

[2] Ministry of Water Resources of the People's Republic of China (2016) Report of China Water Resources in 2016. China Water Conservancy and Hydropower Press, Beijing.

[3] Jiménez, S., Andreozzi, M., Micó, M.M., Álvarez, M.G. and Contreras, S. (2019) Produced Water Treatment by Advanced Oxidation Processes. Science of The Total Environment, 666, 12-21. https://doi.org/10.1016/j.scitotenv.2019.02.128

[4] Rodrigues, M.A.S., Amado, F.D.R., Xavier, J.L.N., Streit, K.F., Bernardes, A.M., et al. 
(2008) Application of Photoelectrochemical-Electrodialysis Treatment for the Recovery and Reuse of Water from Tannery Effluents. Journal of Cleaner Production, 16, 605-611. https://doi.org/10.1016/j.jclepro.2007.02.002

[5] Gonze, E., Comenges, N., Gonthier, Y. and Bernis, A. (2003) High Frequency Ultrasoundas a Pre- or Post-Oxidation for Paper Wastewaters and Landfill Leachate Treatment. Chemical Engineering Journal, 92, 215-225. https://doi.org/10.1016/S1385-8947(02)00258-9

[6] Stasinakis, A.S. (2008) Use of Selected Advanced Oxidation Processes (AOPs) for Wastewater Treatment: A Mini Review. Global NEST Journal, 10, 376-385. https://doi.org/10.30955/gnj.000598

[7] Ismail, A.F. and Matsuura, T. (2019) RO Membrane Fouling. In: Reverse Osmosis, Elsevier, Amsterdam, 189-220. https://doi.org/10.1016/B978-0-12-811468-1.00008-6

[8] Juang, L.C., Tseng, D.H. and Lin, H.Y. (2007) Membrane Processes for Water Reuse from the Effluent of Industrial Park Wastewater Treatment Plant: A Study on Flux and Fouling of Membrane. Desalination, 202, 302-309.

https://doi.org/10.1016/j.desal.2005.12.068

[9] Judd, S. and Jefferson, B. (2003) Membranes for Industrial Wastewater Recovery and Re-Use. Elsevier Science Ltd, London, UK.

[10] Badawy, M.I. and Ali, M.E. (2006) Fenton's Peroxidation and Coagulation Processes for the Treatment of Combined Industrial and Domestic Wastewater. The Journal of Hazardous Materials, 136, 961-966. https://doi.org/10.1016/j.jhazmat.2006.01.042

[11] Abdel-Gawad, S. and Abdel-Shafy, M. (2002) Pollution Control of Industrial Wastewater from Soap and Oil Industries: A Case Study. Water Science \& Technology, 46, 77-82. https://doi.org/10.2166/wst.2002.0556

[12] Bienati, B., Bottino, A., Capannelli, G. and Comite, A. (2008) Characterization and Performance of Different Types of Hollow Fibre Membranes in a Laboratory-Scale MBR for the Treatment of Industrial Wastewater. Desalination, 231, 133-140. https://doi.org/10.1016/j.desal.2007.10.027

[13] Chan, Y.J., Chong, M.F., Law, C.L. and Hassell, D.G. (2009) A Review on Anaerobic-Aerobic Treatment of Industrial and Municipal Wastewater. Chemical Engineering Journal, 155, 1-18. https://doi.org/10.1016/j.cej.2009.06.041

[14] Ahn, Y.T., Kang, S.T., Chae, S.R., Lee, C., Bae, B.U., et al. (2007) Simultaneous High- Strength Organic and Nitrogen Removal with Combined Anaerobic Upflow Bed Filter and Aerobic Membrane Bioreactor. Desalination, 202, 114-121. https://doi.org/10.1016/j.desal.2005.12.046

[15] Zhang, D., Lu, P. and Long, T. (2005) The Integration of Methanogensis with Simultaneous Nitrification and Denitrification in a Membrane Bioreactor. Process Biochemistry , 40, 541-547. https://doi.org/10.1016/j.procbio.2003.11.043

[16] Mulder, A., Graaf, A.A., Robertson, L.A. and Kuenen, J.G. (1995) Anaerobic Ammonium Oxidation Discovered in a Denitrifying Fluidized Bed Reactor. FEMS Microbiology Ecology, 16, 177-184. https://doi.org/10.1111/j.1574-6941.1995.tb00281.x

[17] Strous, M., Kuenen, J.G. and Jetten, M.S.M. (1999) Key Physiology of Anaerobic Ammonium Oxidation. Applied and Environmental Microbiology, 65, 3248- 3250. https://doi.org/10.1128/AEM.65.7.3248-3250.1999

[18] Dvořák, L., Gómez, M., Dolina, J. and Černín, A. (2016) Anaerobic Membrane Bioreactors-A Mini Review with Emphasis on Industrial Wastewater Treatment: Applications, Limitations and Perspectives. Desalination and Water Treatment, 57, 19062-19076. https://doi.org/10.1080/19443994.2015.1100879

[19] Kartal, B., Maalcke, W.J., de Almeida, N.M., Cirpus, I., Gloerich, J., Geerts, W., den 
Camp, H.J.M.O., Harhangi, H.R., Janssen-Megens, E.M., Francoijs, K., Stunnenberg, H.G., Keltjens, J.T., Jetten, M.S.M. and Strous, M. (2011) Molecular Mechanism of Anaerobic Ammonium Oxidation. Nature, 479, 127-130. https://doi.org/10.1038/nature10453

[20] Siegrist, H., Salzgeber, D., Eugster, J. and Joss, A. (2008) Anammox Brings WWTP Closer to Energy Autarky Due to Increased Biogas Production and Reduced Aeration Energy for N-Removal. Water Science \& Technology, 57, 383-388.

https://doi.org/10.2166/wst.2008.048

[21] Ozgun, H., Dereli, R.K., Ersahin, M.E., Kinaci, C., Spanjers, H. and van Lier, J.B. (2013) A Review of Anaerobic Membrane Bioreactors for Municipal Wastewater Treatment: Integration Options, Limitations and Expectations. Separation and $\mathrm{Pu}$ rification Technology, 118, 89-104. https://doi.org/10.1016/j.seppur.2013.06.036

[22] Lin, H., Peng, W., Zhang, M., Chen, J., Hong, H. and Zhang, Y. (2013) A Review on Anaerobic Membrane Bioreactors: Applications, Membrane Fouling and Future Perspectives. Desalination, 314, 169-188. https://doi.org/10.1016/j.desal.2013.01.019

[23] Dereli, R.K., Ersahin, M.E., Ozgun, H., Ozturk, I., Jeison, D., van der Zee, F. and van Lier, J.B. (2012) Potentials of Anaerobic Membrane Bioreactors to Overcome Treatment Limitations Induced by Industrial Wastewaters. Bioresource Technology, 122, 160-170. https://doi.org/10.1016/j.biortech.2012.05.139

[24] Tao, Y., Gao, D.-W., Fu, Y., Wu, W.-M. and Ren, N.-Q. (2012) Impact of Reactor Configuration on Anammox Process Start-Up: MBR versus SBR. Bioresource Technology, 104, 73-80. https://doi.org/10.1016/j.biortech.2011.10.052

[25] van Lier, J.B. (2008) High-Rate Anaerobic Wastewater Treatment: Diversifying from End-of-the-Pipe Treatment to Resource-Oriented Conversion Techniques. The International Association on Water Pollution Research, 57, 1137-1148. https://doi.org/10.2166/wst.2008.040

[26] Visvanathan, C., Ben Aim, R. and Parameshwaran, K. (2000) Membrane Separation Bioreactors for Wastewater Treatment. Critical Reviews in Environmental Science and Technology, 30, 1-48. https://doi.org/10.1080/10643380091184165

[27] Lin, H., Liao, B.-Q., Chen, J., Gao, W., Wang, L., Wang, F. and Lu, X. (2011) New Insights into Membrane Fouling in a Submerged Anaerobic Membrane Bioreactor Based on Characterization of Cake Sludge and Bulk Sludge. Bioresource Technolo$g y$, 102, 2373-2379. https://doi.org/10.1016/j.biortech.2010.10.103

[28] Minami, K. (1994) A Trial of High Performance Anaerobic Treatment on Wastewater from a Kraft Pulp Mill. Desalination, 98, 273-283. https://doi.org/10.1016/0011-9164(94)00152-9

[29] Meng, F., Chae, S.-R., Drews, A., Kraume, M., Shin, H.-S. and Yang, F. (2009) Recent Advances in Membrane Bioreactors (MBRs): Membrane Fouling and Membrane Material. Water Research, 43, 1489-1512. https://doi.org/10.1016/j.watres.2008.12.044

[30] Judd, S. (2011) The MBR Book: Principles and Applications of Membrane Bioreactors for Water and Wastewater Treatment. Second Edition, Elsevier, Oxford.

[31] Yu, L., Zhang, Y., Zhang, B., Liu, J., Zhang, H. and Song, C. (2013) Preparation and Characterization of HPEI-GO/PES Ultrafiltration Membrane with Antifouling and Antibacterial Properties. Journal of Membrane Science, 447, 452-462. https://doi.org/10.1016/j.memsci.2013.07.042

[32] Choo, K.-H. and Lee, C.-H. (1996) Membrane Fouling Mechanisms in the Membrane-Coupled Anaerobic Bioreactor. Water Research, 30, 1771-1780. https://doi.org/10.1016/0043-1354(96)00053-X 
[33] Meabe, E., Deleris, S., Soroa, S. and Sancho, L. (2013) Performance of Anaerobic Membrane Bioreactor for Sewage Sludge Treatment: Mesophilic and Thermophilic Processes. Journal of Membrane Science, 446, 26-33. https://doi.org/10.1016/j.memsci.2013.06.018

[34] Wang, X.R. (2017) Operational Efficiency of Anaerobic Membrane Bioreactor (ANMBR) for Treatment of Domestic Sewage. Master's Thesis, Harbin Institute of Technology, Harbin.

[35] Hu, B.L., Chen, X.L., Zheng, P., et al. (2005) Performance of Two Kinds of Anammox Reactors. Acta Scientiae Circumstantiae, 25, 545-551

[36] Yuan, B., Li, J. and Guo, Q. (2015) Research and Development Direction of Anaerobic Membrane Bioreactor in Wastewater Treatment. Industrial Water Treatment, 35, 1-6.

[37] Martinez-Sosa, D., Helmreich, B., Netter, T., et al. (2011) An Aerobic Submerged Membrane Bioreactor (AnSMBR) for Municipal Wastewater Treatment under Mesophilic and Psychrophilic Temperature Conditions. Bioresource Technology, 102, 10377-10385. https://doi.org/10.1016/j.biortech.2011.09.012

[38] Ramos, C., Zecchinof, E.D., et al. (2014) Chemical Cleaning of Membranes from an Anaerobic Membrane Bioreactor Treating Food Industry Wastewater. Journal of Membrane Science, 458, 179-188. https://doi.org/10.1016/j.memsci.2014.01.067 